Complutense Journal of English Studies ISSN: 2386-3935

\title{
Chingonas and Chingados: Femininity and Machismo in Three Poems by Francisco X. Alarcón
}

Jaime García Iglesias ${ }^{1}$

\begin{abstract}
This article analyzes the ways in which Queer Chicano poet Francisco X. Alarcón presents the interplay of family, sexuality, and heritage in his poetry. Three poems are analyzed: "Cuarto oscuro/Dark Room", "Mi padre/My Father", and "Una pequeña gran victoria/A Small but Fateful Victory". In these pieces, Alarcón negotiates his own identity as an 'Other' of the Chicano Community by emphasizing the performative nature of masculinity and femininity. In so doing, he provides an insight into the dilemmas and fractures of contemporary Chicanos. Thus, this piece aims to also incorporate Alarcón to the Chicano literary canon by studying how his poems echo the theoretical paradigms established by Anzaldúa, Arteaga, and others.
\end{abstract}

Keywords: queer, Chicano, performance, family, poetry.

Contents. 1. Introduction 2. Theoretical Framework 3. Analysis 3.1. "Enclaustradas": The Performative Cell, Foucault, and Gay Sex 3.2. "That nightmare called macho": Toxic Masculinity and the Generational Gap 3.3. El Macho Poniéndose el Mandil: Alternative Masculinities 4. Conclusion.

How to cite this article: García Iglesias, J. (2017) Chingonas and Chingados: Femininity and Machismo in Three Poems by Francisco X. Alarcón, in Complutense Journal of English Studies 25, 159-172.

\section{Introduction}

From Rodolfo “Corky" Gonzáles' 1967 "I am Joaquin” to Donald Trump's speeches, mainstream images of Mexican Americans in the United States are impregnated by fallacies of homogeneity that originate in the early stages of the Chicano Movement (1960s to early 1970s). This faulty narrative of unity is best expressed in Alurista's 1969 "El Plan Espiritual de Aztlán", where he writes the slogan that would be adopted by MeCha: "Por La Raza todo. Fuera de La Raza nada". This summarizes the overwhelming ethnic character of the early Chicano Movement, oblivious to internal diversity. This totalizing perspective was not contested until the late 1970s, by the new Post-Movement activists. For instance, Bernice Rincón, in 1975, rewrote "I am Joaquin" as: "La Raza!/ Mexicana/ Española/ Latina/ Hispana/ Chicana" (Rincón 1975: 52), thus vindicating the role

1 Department of Sociology, University of Manchester (UK)

E-mail: jaime.garciaiglesias@postgrad.manchester.ac.uk 
played by women within the Chicano Movement, which had systematically rendered their voices irrelevant.

If, as Fernández Rodríguez suggests, the early stages of the Chicano Movement argued for an identity "devoid of internal conflicts and fissures" (2008: 31), the Post-Movement inquiry could be articulated by Cherríe Moraga's wondering "[a]fter resistance and affirmation, where do we go? Possibly to a place of deeper inquiry into ourselves and our people" $(1997,180)$. In this statement, Moraga establishes a new framework for the developing Chicano community of artists that encourages diversity and individuality. It is in this very context that we place Queer Chicano poet Francisco X. Alarcón, whose first work, Tattoos, was published in 1985. Alarcón's outsider status stems not only from his queer identity, but from his acceptance of that identity and his permanent attempts at combiningjust like Anzaldúa and Moraga - being Chicano and queer. Of himself, he said that "[a]s a Chicano poet who also celebrates being gay, I have come to realize that I write desde afuera del margen mismo de la sociedad [...], and that for some, even my own gente, I represent the ultimate Other" (Alarcón 1999: 159).

Alarcón's status as "the ultimate Other" may well explain that it has been his children's books that have received critical acclaim and public relevance, whereas his adult work has remained mostly unnoticed except for a few scholars (Rivera 2010; Hernández-G. 2015; Foster 1999). Despite his lack of popularity outside the narrow field of Queer Chicano poetry, Alarcón's work is thick with imagery inherited from Aztec culture and borrowed from American mass media, explicit erotic scenes with powerful conflations of body and geography, and permanent interplays between English, Spanish, Caló, and Nahuatl. This richness may certainly be the product of Alarcón's own life experiences: he was born in Wilmington, California, but soon his family moved to Guadalajara, Mexico, due to financial problems. He returned to the United States at the age of eighteen to work as a migrant farm worker. Despite his untowardly origins, he took his graduate courses at Stanford University, and was eventually awarded a Fulbright Fellowship to Mexico City where he met, in 1982, poet Elías Nadino. Alarcón found in Nadino "his role model and soul mate" (Hernández-G. 2005: 196). Beyond his poetry, Alarcón was impressed with Nadino's open attitude about his homosexuality. He later returned to the United States and worked as a lecturer at the University of California Davis.

Indeed, we can see a parallel between his personal and poetic life that serves to explain some of the features of his poetry: for instance, his grandmother being a speaker of Nahuatl, a Uto-Aztec language, may explain Alarcón's fixation on Aztec languages; and his work as an AIDS activist in San Francisco is accurately represented in his poems "Blues del SIDA/AIDS Blues", "Pro vida/ For Life", and "Preguntas/ Questions". Alarcón passed away on January 15, 2016, at his home in Davis, California, after being diagnosed with stomach cancer the previous year.

Alarcón's own life is the development of sexual and ethnic Otherness. It is that "ultimate Otherness" that this paper aims to present and analyze: the ways in which Alarcón negotiates gender, ethnicity, and sexuality in the face of performative realities within the family. That is, this paper aims to provide a reasoned answer to Gómez-Pena's (1999: 107) question: "Where are the voices of dissent that delineate the boundaries of the abyss? Where are the artists experimenting with the new possibilities of identity?" I do so by combining a close reading of three of 
Alarcón's poems with the theoretical apparatus established by Gloria Anzaldúa's Borderlands ([1987] 2012), Arteaga's seminal Chicano Poetics: Heterotexts and Hybridities (1997), Butler's texts $(1990 ; 2002)$, and Jensen's analysis of masculinity (2007).

\section{Theoretical Framework}

Gómez-Pena wrote: "The border is all we share. La frontera es lo único que compartimos" (1999: 96). This statement helps to better understand the two basic concepts that underlie Chicano Studies: border and borderlands. Although Arteaga defined the US-Mexico border as "a line, half water, half metal" (1997: 6), it is the "emotional residue" (Anzaldúa [1987] 2012: 25) of this "porous frontier" (Arteaga 1997: 69) that gathers the most attention. This liminal space was described by Anzaldúa as "una herida abierta where the Third World grates against the first and bleeds. And before a scab forms it hemorrhages again, the lifeblood of the two worlds merging to form a third country — a border culture" (Anzaldúa [1987] 2012: 25).

The fluidity of the permanent blood-mixing that takes place in the borderlands allows us to understand the hybridity of the bodies that inhabit such contexts. Hybridity, indeed, can be applied to a variety of dimensions of the subject and is best expressed through Anzaldúa's discussion of self-naming:

[W]e call ourselves Mexican, referring to race and ancestry; mestizo when affirming both our Indian and Spanish (but we hardly ever own our Black ancestry); Chicano when referring to politically aware people born and/or raised in the U.S.; Raza when referring to Chicanos; tejanos when we are Chicanos from Texas. ([1987] 2012: 85)

When analyzing Alarcón's poetry, I particularly favor the use of 'mestizo' insofar as Alarcón's work cannot be properly understood without considering the relevance of his Indian inheritance: Alarcón learned Nahuatl (an Aztec language) from his grandmother, and has since translated and written in that language frequently. Alarcón is, thus, a hybrid subject. This hybridity could also be expressed through the notion of 'difrasismo,' a poetic device commonly used in Nahuatl whereby two elements are joined together so as to designate a third new item while still preserving their original meanings (Arteaga 1997: 18). This kind of Bakhtinian dialogue is similar to Arteaga's definition of the hybrid subject as "the site of competing discourses" (1997: 78). In Alarcón we see this permanent process of negotiation between the different forces: those poems that heavily rely on Mexican imagery occur side by side with sexually explicit queer poems set in New York. Juxtaposition takes place even in his own name, as Rivera pointed out in his analysis of Francisco X. Alarcón's work, arguing that " $\mathrm{X}$ ' is a queer letter in the Spanish language [and] an ominous stand-in for whom he [Alarcón] could have been, but now is not, and for his [Alarcón's] extant double-consciousness" (2010:107). 
Moraga charged the borderlands with the role of contesting the grand narratives of cultural descent: "being Chicana is a politics of refusal to disappear, but it is not, in and on itself, a politics of reproduction" (Arteaga 1997: 37). In so doing, she aimed to subvert the gendered cultural reproduction established since the times of Cortés and Malinche, whose sexual encounter would not only give rise to the mestizos, but also mark the former as chingón, and the latter as chingada. Having established that La Raza is reproduced through the imbalanced heterosexual encounter between chingón and chingada, "the subject of hybridity plays itself out in heterotextual discourse, conceived from the model of heterosexual intercourse, according to which, Chicano subjectivity is understood to reproduce" (Arteaga 1997: 27). Alarcón's choice to accept his own hybrid identity is, therefore, a sexually and politically meaningful decision.

Anzaldúa's efforts to create a new ethnic reality in the borderlands, however, would be naively understood if they were only considered at the literal-textual level. What Anzaldúa and Moraga, as well as many other queer Chicano authors, are aiming at is the deconstruction of the compulsory heterosexuality that denies them full membership of their Familia; the role of the father is superseded and reproduction becomes a monogamous affair. Thus, this new system of reproduction implies a paradigmatic change whereby the intercultural intercourses of heterosexuality become the interlingual relationships of poetry in the homosexual framework (Arteaga 1997: 36). In subverting the roles of chingón/chingada, this new consciousness allows for an unguarded glance at the gender roles of La Raza:

What was missing was a portrait of the sexuality of men and womenindependent of motherhood and machismo-images of the male body as violador and vulnerable, and of the female body as the site of women-defined desire. There was no visible gay and lesbian response to our chicanidad that would challenge the institutionalized and mindless heterosexual coupling, no breakdowns and shake-up of La Familia y La Iglesia, no portrait of our isolation, or machismo as monstruo, of la indígena erased and muted in the body of la chicanita. (Moraga 1997: 180)

Moraga's claim can be summarized in what she calls "an honest portrait of our pain" (1997: 180). Queer Chicanos have been at the forefront of this painful task. Anzaldúa argues that "[t]he queer are the mirror reflecting the heterosexual tribe's fear: being different, being other and therefore lesser, therefore sub-human, inhuman, non-human" (Anzaldúa [1987] 2012: 40). Alarcón's poetry is ridden with this same conflict between acceptance and rejection. This rejection is essentially triggered by the fact that queer men and women (and, more so, queer Chicano poets) rupture not only the hegemonic sexual politics of their society, but - in this case - the politics of cultural descent, of national belonging, and of linguistic belonging (Rivera 2010: 98). In so doing, they are fracturing the nationalistic claims of their groups; they pose an internal threat of dissent.

It is in the context of Post-Movement Chicano literature, which enriches $L a$ Revolución by adopting feminist and queer demands, where we find Alarcón, who is in a sense, a second-class citizen of his respective Nation-States, [and 
who] develops the notion that fleeing may not be a requirement to feel alien in one's own skin or one's own language. Non-belonging allows for the possibility to experiment, it opens a space for play. (Rivera 2010: 107)

Alarcón, thus, denounces the social and political injustices Chicanos endure, but also criticizes the degree of internal discrimination existing within La Familia. He revisits his memoires and his own upbringing to renegotiate his identity and to illustrate a poetic universe where there are not only chingones and chingados, but also chingoNAS and chingadOS.

\section{Analysis}

Alarcón's engagement with the social and sexual constrictions of heterotextual culture imprints his poetry throughout. From his early Tattoos (1985) to his latest Canto hondo|Deep Song (2015), Alarcón developed a tone that is both questioning and hopeful. His poetry encompasses both overt criticism of racial and gender dynamics, and romantic and sexual poems. In so doing, he reflects the myriad of contexts he has experienced: from the traditional life during his youth, to the openness of San Francisco's Mission District in the 1980s, to his possible romance with Mexican poet Elías Nadino, one of Mexico's most preeminent authors. Thus, Alarcón's poetry can be divided in two distinct groups: poems that deal with sexuality and romance ("Eros", "Mi Cama|My Bed") and poems that focus on social commentary ("Prófugo|Fugitive", "Oración|Prayer"). From this second group, I will analyze three poems: "Cuarto oscuro|Dark Room", "Mi padre|My Father", and "Una pequeña gran victoria|A Small but Fateful Victory", all present in his 2002 anthology From the Other Side of the Night|Del otro lado de la noche.

These three poems represent a constant axis in Alarcón's poetic oeuvre: first published in his acclaimed Body in Flames|Cuerpo en Llamas (1999), and reprinted in the 2002 anthology From the Other Side of the Night, these pieces have undergone few stylistic changes and remained as a single unit, representing Alarcón's profound engagement with the subject matter at hand: family politics. Alarcón and Francisco Aragón, who has translated most of his work, "often engage in bilingual games between original and translation [...] perform[ing] the sexualized mystical fusion his [Alarcón's] poems bespeak" (Rivera 2010: 99). Indeed, the politics of language in Alarcón are worth a closer look. First, we must understand that any linguistic choice within poetry at large, and specially in Chicano poetics, is loaded with political meaning. Second, that Alarcón is not necessarily a bilingual poet, but a multilingual one that speaks Standard American English, Standard Spanish, Mexican Spanish, Caló, Nahuatl, and Chicano Spanish.

Alarcón admitted that his languages allowed him to access different parts of his memories (Reading Rockets 2011). This phenomenon has been explained by Hernández-Mora: "el accesso indiferenciado a lo simbólico de cada lengua [...] crea una marcada diferencia entre el sujeto cultural chicano y su mundo propio: un mundo público (que tiende a nombrar en inglés) y uno privado, más subjetivo que el anterior, que pareciera estar lleno de ausencias" (2003: 27). Finally, we must acknowledge that Alarcón's poetry is not bilingual, but "interlingual" in so much as it does not combine English and Spanish only, but "juxtaposes them" 
syntactically and poetically, creating "reverberations and images [that] interlock, pulling in two directions at once" (Sánchez 1985: 21). The interlingual unit is not the poem, but the line, even the word. These complex language politics represent the conflictive relationship that many bilingual and multilingual speakers establish with their languages (Rivera 2010: 99).

\section{1. "Enclaustradas": The Performative Cell, Foucault, and Gay Sex}

"Cuarto oscuro | Dark room" opens the sequence of the poems I am going to analyze. Although it features a deceptively innocent three-line stanza, the prevalence of enjambment and the absence of punctuation and capitalization challenge continuous reading, forcing the readers to pause upon each word. It is in those compulsory hiatuses when the reader appreciates the connotations of individual words and the reduplication of meanings. In this poem, Alarcón uses the metaphor of a "dark cell" to represent the space of performative oppression where women live. However, I will also argue that he intentionally creates an ambiguous homoerotic image (the dark room) to establish a parallel between women's and gay men's subjugation.

As in many of Alarcón's poems, the title directly refers to the contents of the piece. In this case, the title "Cuarto oscuro|Dark Room" works to emphasize Alarcón's main focus: the "dark room" as a metaphor of structural oppression (it exists in "every house"). A multilingual approach seems to be a requisite for analyzing these first lines of the poem and to clarify whether Alarcón refers to this "dark room" as an actual physical space or as a performative one in "en cada casa/hay un cuarto/oscuro". First, it should be noted that - in the English versionthe emphasis seems to be placed upon physicality by using "house" (instead of "home") and "hidden/by the walls/of other rooms". However, when we conflate this version with the Spanish one, certain issues arise that point towards a performative reading of the poem: "hidden" would basically translate as 'escondida,' yet in Alarcón's poem it is translated as "enclaustrada". This word has many connotations that are not present in the English "hidden": essentially, the Real Academia Española lists as one of the word's definitions "apartarse de la vida social para llevar una vida retirada", as well as "encerrar en un claustro". Thus, "enclaustrada" does not necessarily mean to be concealed but is loaded with the more performative sense of a "vida retirada". We are now prepared to re-read the whole first two stanzas under this new performative light: the "cell" would be demarcated not by physical walls, but by the roles and duties women would be expected to perform in each other room of the house. As Butler argues: "gender proves to be performance" (1990: 25).

This performative reading is further emphasized in the third and fourth stanzas. The "dark room" "doesn't seem/to bother/men" who "consider it/the most normal/thing in life". Men's apparent disregard for this space underscores the idea that the performative space of the dark room is anchored in patriarchy, and that it has been consequently historicized, naturalized and legitimized by the dominant discourses of machismo. One should note, however, that Alarcón does introduce the modifier "seem" in "it doesn't/seem/to bother men" (emphasis added). In so doing, he hints at the fact that men's lack of concern with the room's existence does not preclude them from being affected by that same structure. Rather, as we 
will later see in the analysis of "Mi padre|My Father", Alarcón is well aware of the oppression exerted upon men so that they abide by the "rules" of being a "macho".

The last two stanzas of the poem further characterize the "dark room" as a windowless space and as a "cell". The use of "cell" could be understood to be a critique of the role la Religión plays in supporting dominant discourses of gender in Chicano culture ("cells" are the living quarters of a convent). While this reading would work as an echo to the religious trait of the previous "enclaustrada", I would like to posit that Alarcón is also re-emphasizing the structural nature of the oppression: the Spanish parallel of "cell" used by Alarcón and Aragón, "mazmorra", points to a more political and institutionalized concept: the group of cells, the prison.

In this sense, we can see plenty of parallels between the workings of Foucault's panopticon and the ideas that underlie the "cell" as presented in Alarcón's poem: the panopticon is not a reality that can be built but a situation that has to be produced. In a similar way, the "cell" is not a real physical location within a house, but a performative space. Those who inhabit that "cell" are not imprisoned by others who hold the key to their door, because such a door does not exist: it is both permanently closed and open. The subjects of the panopticon, just like those who live in Alarcón's cell, have internalized their role, their oppression as spelled out by the dominant discourse, and hold themselves prisoners without a guard. It is true, nonetheless, that both the religious reading (where the "mazmorra" echoes the Spanish Inquisition) and the structural one (where "mazmorra" refers to the state prisons) can be found in this poem. However, when reading this piece alongside the other poems in this paper, I favor the structural and performative one.

To close the poem, Alarcón writes "but there inside/ that cell without/ windows live/ the mother/ the daughter/ the wife". He represents women in the state of deprived agency that hegemony creates, and, consequently, names them in relation to their roles in La Familia: "the mother" who gives birth to "the daughter" who, in turn, becomes "the wife". In this cyclical stanza, we see how the women Alarcón talks about have internalized their own roles and the expectations society has for them, which include the acceptance of their male counterparts' rules. Certainly, we cannot say that Alarcón supports this positioning, for he will further discuss men's presence in that cell in "Mi padre|My Father" and women's breaking out of the "cell" in "Una pequeña gran victoria|A Small but Fateful Victory".

A point worth raising as regards this poem is the homoerotic ambivalence of the term "dark room|cuarto oscuro". As a matter of fact, there are many other poems of Alarcón's that allow for Chicano and homoerotic readings at once, such as "Prófugo" (2002). In "Dark Room", it should be mentioned that "dark room" is a term commonly used in gay slang to refer to the scarcely lit backrooms present in certain bars where men engage in anonymous sex with other men. Whereas the "dark room" is an oppressing "cell" for women in "Cuarto oscuro|Dark Room", the gay "dark room" is a space of freedom. Allan Berubé, in his landmark "The History of Gay Bathhouses" ([1984] 2003) argues that these spaces were "safety zones where it was safe to be gay" (34). Darkrooms, in particular free men from several constraints: society's frowning at gay intercourse, monogamous expectations, and body dismorphia. Whereas women's dark room is a "cell" of oppression, men's is a space of liberation. 


\section{2. "That nightmare called macho": Toxic Masculinity and the Generational Gap}

The notion of masculinity is essential to understand the way in which "Mi padre|My Father" is articulated. Masculinity, or the performance society expects from those identified as men, may at times be described as "toxic masculinity" (Jensen 2007). This kind of masculinity becomes too overpowering, too constricting for men, too "toxic". Jensen has argued that being "a man, then, typically translates as: surrender your humanity" $(2007,5)$. He further develops this kind of masculinity with a simile, the game King of the Hill, explaining that "toxic masculinity" is the kind of behavior that allows you to be King of the Hill, but that, at the same time, prevents that power from being shared with others; it is a precarious and contingent sense of dominance that creates a permanent state of anxiety leading to a life-long fear of not living up to other men's expectations and of being dethroned. Toxic masculinity is, essentially, machismo. This sense of decayed masculinity, of machismo, is further developed by Anzaldúa from the ethnic perspective of the border clash:

His [today's Chicano men's] 'machismo' is an adaptation to oppression and poverty and low self-esteem. It is the result of hierarchical male dominance. The Anglo, feeling inadequate and inferior and powerless, displaces or transfers these feelings to the Chicano by shaming him. (Anzaldúa, [1987] 2012, 105)

This kind of toxic masculinity or machismo is what we can fully appreciate in Alarcón's "Mi padre | My Father". In this poem, characterized by its militaristic semantic field, the figure of the father is rendered as being both an enemy and a comrade. Alarcón plays with the topics of masculinity, but also with the generational gap. The text can be divided into two sections: a first one delineated by coldness and distance, and a second one that is warmer in tone and that portrays an opening of understanding between the poetic persona and the father, which allows them to situate themselves against the common enemy of machismo.

The coldness of the first section is evident in the opening stanza: "my father/ and I greet/ each other", paralleled in Spanish by "saludamos". This kiss-less, hugless, love-less greeting is, furthermore, "guarded/ as if/ sealing/ a truce". Alarcón returns to the militaristic semantic field to represent the apparent distance and opposition between his father and himself. Indeed, the poem is an interplay with readers' expectations: the "sealing" that takes place in the second stanza is only resolved in the third, after a blank space and a silence, where the reader realizes that what is being sealed is "a truce" or "una tregua". The feebleness of this action is emphasized by the fact that the two contenders have not even left the "battlefield" but remain on it ("a truce/ on a/ battlefield"), ready to retaliate if necessary. Therefore, in this first section, Alarcón establishes a link similar to the one he proposed in "Consejos de una madre", an unstable balance between coldness and love.

It is during the second part of the poem that we reach a deeper understanding of the father's psyche, as the poem argues that "beneath it all/ he too/ rejects/ that affliction/ that folly/ that nightmare/ called macho". The poetic persona acknowledges his father's oppression as well as his own: despite the use of 
"that"-which could indicate a degree of separation - the author recognizes that machismo is his "too". This occurs in terms that are similar to those of Anzaldúa's when she argued that she "abhor[s] how my [her] culture makes macho caricatures of its men" (Anzaldúa [1987] 2012: 43). By using terms such as "folly" and "caricature", Alarcón and Anzaldúa return to the performative and contingent nature of masculinity.

In the last stanza we can appreciate an important linguistic change: whereas the 1990 edition of the poem (in Body in Flames|Cuerpo en llamas) ends as "that nightmare/ called/ man", the 2002 reprinting in From the Other Side of the Night|Del otro lado de la noche changes the word "man" for "macho", concluding in the following way: "that nightmare/ called/ macho". This is a conceptual narrowing from the binary notion of gender to the performative macho, which is, in itself, a kind of masculinity, a toxic one indeed, but by no means the only one available to men.

There are several key issues Alarcón points out with this poem: the generational gap existing among Chicanos, the consequences of machismo for men, and the performative nature of machismo itself, which will be dealt with in the following section.

\subsection{El Macho Poniéndose el Mandil: Alternative Masculinities}

The generational gap between mother and daughter is also the theme of "Una pequeña gran victoria|A Small but Fateful Victory", the last of Alarcón's poems I will close-read. In this piece, Alarcón establishes a poetic persona that narrates a childhood memory: the daughter refuses to do the dishes, and - after a moment of tension - it is the father that stands up and cleans them. Formally, this poem is certainly richer than the previous two, with more complex syntactic structures and longer sentences. This text summarizes the issue of femininity and performative imprisonment of "Cuarto oscuro|Dark Room" and the complexities of machismo and generational gaps of "Mi padre|My Father". It takes the form of a revisited childhood scene that is now analyzed from the poetic persona's enhanced awareness of hegemony and patriarchy. More closely resembling the kind of conflict that can be seen in "Mi padre|My Father" or in Anzaldúa's violent "We Call Them Greasers" (Anzaldúa [1987] 2012: 156), this poem distances itself from the conceptual abstraction of "Cuarto oscuro|Dark Room". The fact that it is anchored in the texture of everyday life allows the poetic persona to endow this relatively small fight with greatness and significance: it may indeed be a "small" victory, but it is certainly a "fateful" one in the life of its characters. This 'fateful[ness]' permits Alarcón to present a poem that is both critical of patriarchy and optimistic about the power of generational change, which may not only affect the younger generations, but also modify the attitudes of the older ones. In addition, Alarcón also directly breaks the cycle mother/daughter/wife he portrayed in "Cuarto oscuro|Dark Room": the daughter is here a responsive force that demolishes the "cell" of patriarchy, and-in so doing-also articulates the arguably unconscious or suppressed desires of her mother. Furthemore, the daughter's rebellion triggers a change in her father's performance of gender.

The narrative quality of the poem is evident from the onset when Alarcón writes: "esa noche de verano". The poetic persona, then, focuses on the sister who 
refused to do the dishes "anymore" (in the 2002 edition) and, more strongly, "never again" (in the 1999 version). The visual shape of the poem on the page serves to mark the turning point in the story: the "no", in italics and centered, serves as a focal point for the reader. It is from that "no" onwards that the subsequent and responsive action takes place.

The next two stanzas are devoted to analyzing what the mother may have been thinking: "my mother only/ stared at her/ maybe wishing". The relevance of "only" is worth noting: the enjambment so common in Alarcón is truly ambiguous here, as we could assume that "only" the mother is staring at the sister- the men, probably anticipating the likely conflict, look away - or that the mother can do nothing but "stare", because her agency has been suppressed due to her condition of male surrogate, and her daughter's regained agency startles her. I do favor this second reading inasmuch as the subsequent lines further specify what the poetic persona believes the mother was thinking: "maybe wishing/ she had said/ the same thing/ to her own mother". Alarcón delays narrating the father's resolution and, instead, chooses to focus on the mother's psyche. In this close-up, we see the reappearance of the "dark room", as the mother remembers - through the son's poetic voiceher own "cell": "she too had hated/ her "woman' chores/ of cooking cleaning/ always looking after/ her six brothers/ and her father". The poetic voice concedes that the gender characterization of those chores is well worth the use of questioning quotation marks. However, the mother realizes her own inability to break free from patriarchy insofar as she is a surrogate figure, as her mother was. The silence of the brothers does not only emphasize the main action, but serves to represent the fragility of hegemonic masculinity: the "small but fateful" "no" uttered by the sister is endowed with enough power to destabilize their conceived notions of gender roles. Thus, they wait, expecting to see what the father, who is supposed to be a more developed macho, does. It is curious that Alarcón, through the poetic voice, is perfectly able to guess what the sister and mother may have been thinking, but avoids entering the minds of his brothers or, later, his father.

After this lapse in action, the poetic voice regains the command of the narration and moves to a wider frame. In so doing, we gain conscience - or rather, are reminded - of the essential turning point of the "no", as "a small thunderclap/ shook the kitchen". The father breaks the "sudden impasse" by wearing an apron and starting to do the dishes himself. Unlike the case of the mother and sister, we get here no information about the reasoning behind his actions. Again, at the end, Alarcón closes the frame upon the mother and sister, once more accessing their thoughts: "I could almost hear/ the sweet music of victory/ ringing/ in my sister's ears/ in my mother's smile". It is true that with that "could almost", Alarcón recognizes his eventual inability to fully comprehend the female psyche.

This poem, overall, shares with "Mi padre | My Father" the military tone ("sudden impasse", "victory"), and with both Anzaldúa and Moraga the subject matter of family portrayals. However, unlike Borderlands or Shadow of a Man, Alarcón's poem stands out for its optimistic outlook: not only has the sister broken the performative "cell", but the father seems to have acknowledged the breaking, and he has actively, albeit reactively, challenged machismo himself by adopting a performance that would not be acceptable for a macho. It is unclear whether the father would have been willing to adopt that deviant performance if his daughter had not revolted. Similarly cryptic is the brothers' attitude and the extent to which 
their father's actions have helped to make them more aware. However, I do believe that their silently waiting to see what the father would do after the "sudden impasse" reveals a degree of uncertainty about their sister's role and their own performance. Thus, we may believe that they indeed were open to accept their father's new performance as legitimate.

\section{Conclusion}

In the three poems analyzed herein, Alarcón articulates notions essential to feminist criticism and masculinities studies. In "Cuarto Oscuro | Dark Room", he establishes the kind of performative imprisonment women embody in La Familia, in addition to the cyclical nature of patriarchy. He also allows for his queer identity to transpire through the very term "dark room". In this first poem we can already perceive the constructive juxtaposition of queer and Chicano readings. Similarly, in "Mi padre|My Father", he emphasizes machismo as a performative fallacy, and the consequences of this type of toxic masculinity. Lastly, in "Una pequeña gran victoria" he combines these two aspects into an almost diary-entry-like poem, where we best appreciate his optimistic outlook on the possibilities of renewal that come from new generations. Alarcón himself is a new generation: he is distant from the early Movement poetry of Gonzáles and from Aztlán. He adapts seminal texts to Post-Movement themes and to his own personal struggles as a queer man. He performs the hybridity characteristic of border bodies. By doing so, he is creating a new canon where divisiveness is not perceived as a fracturing but as a cohesive device. He is a 'difradic' subject: his identities are not simply juxtaposed but, as in Nahuatl poetry, they create a new identity while not completely eroding the particularities of his varied backgrounds. This is best exemplified by the fact that, for instance, Alarcón would open his poetry recitals by performing the ancient chant of Tahui, then moving to read heavily homoerotic pieces. Both performances neither block nor overpower each other: they create a new framework for the understanding of Alarcón's Chicano identity as based on tradition and queerness. As far from the panegyric tone of "I am Joaquin" as from the responsive style of Tafolla's "Yo Soy La Malinche" (Tafolla 2016), Alarcón creates a poetry that can be used to bridge gender, sexual, and racial differences, as well as to unite victims and victimizers as partakers in the same system of oppression. Last but not least, he detaches the idea of chingón and chingada from their gender roots and acknowledges that everybody can be chingon@s, just as they can be chingad@s. In so doing, he uproots the cultural base of traditional gender roles, in a way similar to Moraga's Shadow of a Man ([1940] 1994). In both works, the authors rip the veils of cultural tradition to reveal the daily details of oppression in the family setting.

Alarcón argued that "it's important to that you write about your family" (Reading Rockets 2011). La Familia is a basic tenement of Chicanismo. Indeed, Anzaldúa also pointed that "[t]he welfare of the family, the community, and the tribe is more important than the welfare of the individual. The individual exists first as kin - as sister, as father, as padrino - and last as self" (Anzaldúa [1987] 2012, 40). Queer Chicanos such as Anzaldúa, Moraga, or Alarcón perceive themselves to have been 'othered' from their communities, from their families. 
They fear being rejected. Yet that fear, as we have seen in Alarcón, departs from an innate desire to be a member of La Familia, the Chicano world.

That world, precisely, is a growing one. According to the latest predictions of the US census, Latinos (among them, Chicanos) will conform half of the population of the country by 2050 . In fact, they are no longer a minority, but a majority which is decisive in democratic processes such as presidential elections (Basler 2008). How come we still accept the narratives of uniformity and homogeneity that conflate all the Chicano diversity into a single minority? We need to revise the canon in the light of the Post-Movement politics. When will we hear the Chicano transsexual voice? When will the Chicano body reach magazine covers? Where are the deviant voices that are double-silenced? I opened this article with a question by Gómez-Pena $(1999,107)$ : "where are the voices of dissent that delineate the boundaries of the abyss? Where are the artists experimenting with the new possibilities of identity?" Alarcón may, indeed, be part of the answer.

\section{References}

Alarcón, Francisco X. (1985). Tattoos. Vermont: Nomad Press.

Alarcón, Francisco X. (1990). Body in Flames/Cuerpo en Llamas. San Francisco, CA: Chronicle Books.

Alarcón, Francisco X. (1999). "The Poet as the Other". In D.W. Foster and David Williams, eds., 159-174.

Alarcón, Francisco X. (2002). From the other side of the night/Del otro lado de la noche: new and selected poems. Tucson: University of Arizona Press.

Alarcón, Francisco X. (2015). Canto hondo/Deep Song. Tucson: University of Arizona Press.

Alarcón, Francisco X. and Maya C. González ([1997] 2005). Laughing Tomatoes and Other Spring Poems/Jitomates Risueños y Otros Poemas de Primavera. San Francisco, CA: Children's Book Press.

Alarcón, Francisco X. and Maya C. González ([1998] 2005). From the Bellybutton of the Moon and Other Summer Poems/Del Ombligo de la Luna y Otros Poemas de Verano. San Francisco, CA: Children's Book Press.

Alurista (1969). "El Plan Espiritual de Aztlán". $<\mathrm{http}$ ://classes.sscnet.ucla.edu/00W/chicano101-1/aztlan.htm> (Accessed April 16 2016).

Anzaldúa, Gloria ([1987] 2012). Borderlands/La Frontera: The New Mestiza. San Francisco, CA: Aunt Lute Books.

Arteaga, Alfred (1990). Chicano poetics: Heterotexts and Hybridities. Cambridge: Cambridge University Press.

Basler, Carleen (2008). "White Dreams and Red Votes: Mexican Americans and the Lure of Inclusion in the Republican Party". Ethnic and Racial Studies 31.1: 123-166. doi: $10.1080 / 01419870701538950$

Berubé, Allan ([1984] 2003). "The History of Gay Bathhouses". Journal of Homosexuality 44.3: 33-53. doi: 10.1300/j082v44n03 03.

Butler, Judith (1990). Gender Trouble: Feminism and the Subversion of Identity. New York: Routledge.

Butler, Judith (2002). "Is Kinship Always Already Heterosexual?" Differences 13.1: 1444. doi:10.1215/10407391-13-1-14.

Corpi, Lucha, ed. (1997). Máscaras. Berkely: Third Woman Press. 
Fernández Rodríguez, Carolina (2008). "Between Güeras and Carnales: Chicana Feminist Writers and their Search for a Room of their Own". BABEL-AFIAL 17: 23-47.

Feyder, Linda, ed. (1994). Shattering the Myth: Plays by Hispanic Women. Houston: University of Houston.

Foss, Sonja K, Mary E. Domenico, and Karen A. Foss (2013). Gender Stories: Negotiating Identities in a Binary World. Long Grove: Waveland Press.

Foster, David William, ed. (1999). Chicano/Latino Homoerotic Identities. San Francisco: Cleis Press.

Foucault, Michael ([1975] 1995). Discipline and Punish: The Birth of the Prison. New York: Vintage Books.

Garni, Alisa (2010). "Mechanisms of Migration: Poverty and Social Instability in the Postwar Expansion of Central American Migration to the United States". Journal of Immigration and Refugee Studies 8.3: 316-338. doi: 10.1080/15562984.2010.501295.

Gómez-Pena, Guillermo (1991). "Border Culture: The Multicultural Paradigm". In The Decade Show: Frameworks of Identity in the 1980s, 93-103.

Gonzales-Berry, Erlinda and Shaw N. Gynam (1989). "Chicano Language". In F.A. Lomelí, and Carl R. Shirley, eds., 304-308.

Gonzáles, Rodolfo 'Corky' ([1967]). “I am Joaquin”. $<$ http://www.latinamericanstudies.org/latinos/joaquin.htm> (Accessed April 15 2016).

González, Rigoberto (2016). "Voices: Remembering Friend, Mentor and Poet Francisco X. Alarcón". NBC News, January 27. <http://www.nbcnews.com/news/latino/voicesremembering-friend-mentor-poet-francisco-x-alarcon-n498201> (Accessed February 8 2016).

Grindstaff, Laura and Emily West (2011). "Hegemonic Masculinity on the Sidelines of Sport”. Sociology Compass 5.10: 859-881. doi: 10.1111/j.1751-9020.2011.00409.x.

Hernández-G., Manuel de Jesús (2002). "Poetry as Constructing Identity: Marginality, Social Commitment, Multivalent Love, Indiannes, and Feminism". Afterword to From the Other Side of the Night | Del otro lado de la noche: New and Selected PoemIn Alarcón, by Francisco X. Alarcón, 195- 204. Tucson: University of Arizona Press.

Hernández-Mora, Judith (2003). "El Chicano Imaginado ¿o el Chicano que se Imagina?" Reencuentro 37: 23-27.

Herrera-Sobek, Maria and Helena María Viramontes, eds. (1996). Chicana Creativity and Criticism. Albuquerque: University of New Mexico Press.

Jensen, Robert. (2007). Getting Off: Pornography and the End of Masculinity. Cambridge, MA: South End Press.

Leovy, Jill (2016). "Francisco Alarcón dies at 61; Chicano poet and children's author" Los Angeles Times, January 20. <http://www.latimes.com/local/obituaries/la-me-franciscoalarcon-20160121-story.html> (Accessed February 8 2016).

Lomelí, Francisco A. and Carl R. Shirley, eds. (1989). Chicano Writers: First Series. Detroit: Research Gate.

Márquez, Antonio (1989). "Literatura Chicanesca: The View from the Without". In F.A. Lomelí and Carl R. Shirley, eds., 309-315.

Moraga, Cherríe ([1990] 1994). Shadow of a Man. In Feyder, Linda, ed., 11-49.

Moraga, Cherríe (1997). "En Busca de la Fuerza Femenina". In Corpi, Lucha, ed., 179-187.

Moreman, Shane T. and Persona Non-Grata (2011). "LearnignLearning from and Mentoring the Undocumented AB540 Student: Hearing an Unheard Voice". Text and Performance Quaterly 31.3: 303-320.

Quiñónez, Naomi (1996). La Diosa in Every Woman. In M. Herrera-Sobek and Helena María Viramontes, eds., 104-107.

Reading Rockets. (2011). "Francisco X. Alarcón" (video). Interview. $<$ https://www.youtube.com/watch?v=TMBSb_6LjCE $>$ (Accessed February 8 2016).

Rincón, Bernice (1975). “Chicanas on the Move". Regeneración 2.4: 52. 
Ritcher, David H. (2007). The Critical Tradition: Classic Texts and Contemporary Trends. Boston, MA: Bedford/St. Martin's. 1707-1720.

Rivera, Juan Pablo. (2010). "To Make 'the One' Impossible: Multilingualism and Samesex Desire in the Poetry of Francisco X. Alarcón”. Confluencia 26.1: 98-111.

Rodríguez-García, Vanessa (2007). Review of Conversations with Contemporary Chicana and Chicano Writers, by Héctor A. Torres. A Journal of the Céfiro Graduate Student Organization 7.1-7.2.

Sánchez, Marta Ester (1985). Contemporary Chicana Poetry: A Critical Approach to an Emerging Literature, 1-23. Berkeley: University of California Press.

Shirley, Carl R. and Paula W. Shirley. (1988). Understanding Chicano Literature. 1-62. Columbia: University of South Carolina Press.

Smithsonian NMAI (2015). "Día de los Muertos Festival 2015 - Poetry by Francisco X. Alarcón" (video). Poetry reading at Rasmuson Theatre of the National Museum of the American Indian, October 31, 2015. <https://www.youtube.com/watch?v=ngYK4AjMBY > (Accessed February 8 2016).

Tafolla, Carmen. "La Malinche". Women in World History. $<$ http://chnm.gmu.edu/wwh/modules/lesson6/lesson6.php?s=10> (Accessed February 8 2016).

The Decade Show: Frameworks of Identity in the 1980s (1991). Exh. cat., Los Angeles: Museum of Contemporary Hispanic Art, New Museum of Contemporary Art, and Studio Museum of Harlem.

Urciuoli, Bonnie (1995). "Language and Borders". Annual Review of Anthropology 24: 525-546. 